\title{
PENGARUH PROFITABILITAS TERHADAP HARGA SAHAM PERUSAHAAN SEKTOR INDUSTRI BARANG DAN KONSUMSI DI BEI TAHUN 2017-2020
}

\author{
Mohammad Rizqi Hisbullah \\ Universitas Negeri Surabaya \\ mohammad.17080574133@mhs.unesa.ac.id
}

\begin{abstract}
The stock price can measure effectiveness and company worth. This research aims to affect the company's ability to profit on the stock worth in the consumer goods industry. This research population is the consumer goods industry on The Indonesian Stock Exchange (IDX) from 2017-2020. The sample's selection method uses purposive sampling. Sampling criteria are companies listed on the Indonesia Stock Exchange in the industrial sector of goods and consumption that are not delisted and provide the information needed during 2017 to 2020 , respectively. The number of data is one hundred and twenty (120). Data analysis use multiple linear regression by SPSS Statistics 26 for Mac from IBM. The effect of return on equity on stock price is significant positivereturn on assets and net profit margin no significant effect on stock return. Companies need ROE to attract investors. The increase in ROE will affect the increase in stock prices.
\end{abstract}

Keywords: NPM; ROA; ROE; stock price

\section{PENDAHULUAN}

Elemen dan indikator krusial dalam mengukur kesejahteraan pemegang saham adalah harga saham. Menurut Hartono (2016:180) nilai dan efektivitas dari suatu perusahaan ditunjukkan dengan harga sahamnya. Harga saham menjadi penting bagi perusahaan karena merupakan refleksi dari mutu perusahaan di mata Investor (Rahayu dan Sari, 2018). Semakin tinggi harga saham dalam nilai, semakin tinggi nilai perusahaan dan juga sebaliknya. Saham adalah salah satu sumber pendanaan untuk aktivitas operasi yang bertujuan untuk memaksimumkan kekayaan pemegang saham.

Indeks pasar saham adalah cerminan sekumpulan saham berupa pergerakan harga yang dikategorikan berdasarkan metodologi dan kriteria tertentu yang juga dievaluasi secara berkala dalam sebuah tolok ukur berbasis statistik (Bursa Efek Indonesia, 2021). Karena indeks menginformasikan tentang harga saham yang ada di pasar, secara tak langsung ada mutu perusahaan yang juga diinformasikan di dalamnya. Terdapat 38 indeks dalam Bursa Efek Indonesia (BEI), salah satunya adalah indeks saham sektoral yang merupakan suatu kumpulan harga dari saham perusahaan yang terdaftar di 9 sektor antara lain aneka industri; keuangan; industri barang dan konsumsi; perdagangan, jasa, dan investasi; industri dasar dan kimia; properti dan real estate; pertambangan; dan transportasi dan infrastruktur (Bursa Efek Indonesia, 2018). Menurut Kepala BPS, industri barang dan konsumsi merupakan salah satu sektor yang stabil dalam kondisi penurunan daya beli masyarakat (DetikFinance, 2017).

Tingkat konsumsi masyarakat atas barang dan jasa adalah cerminan daya beli masyarakat atau produk domestik bruto (PDB) (Karya dan Syamsuddin, 2016:67). PDB adalah pendapatan total dari setiap orang yang ada dalam suatu perekonomian (Mankiw, 2010:17). BPS menyatakan PDB adalah indikator ekonomi makro yang menunjukkan arah pertumbuhan ekonomi negara tiap tahun secara keseluruhan (BPS, 2021). Pendekatan produksi, pendapatan, dan pengeluaran akan menghasilkan angka yang sama dalam menghitung PDB. Pendekatan pengeluaran menghitung konsumsi masyarakat untuk barang dan jasa akhir (BPS, 2021).

Berdasarkan gambar 1, sejak 2017 hingga 2020, terjadi penurunan PDB di tahun 2020 menjadi 2,07\%. Tahun 2017 hingga 2019 stabil pada angka 5\%. Terjadi anomali antara PDB dan harga saham dari sektor industri barang dan konsumsi yang membuat sektor tersebut layak untuk dikaji. 
Mohammad Rizqi Hisbullah. Pengaruh Profitabilitas terhadap Harga Saham Perusahaan Sektor Industri Barang dan Konsumsi di BEI Tahun 2017-2020

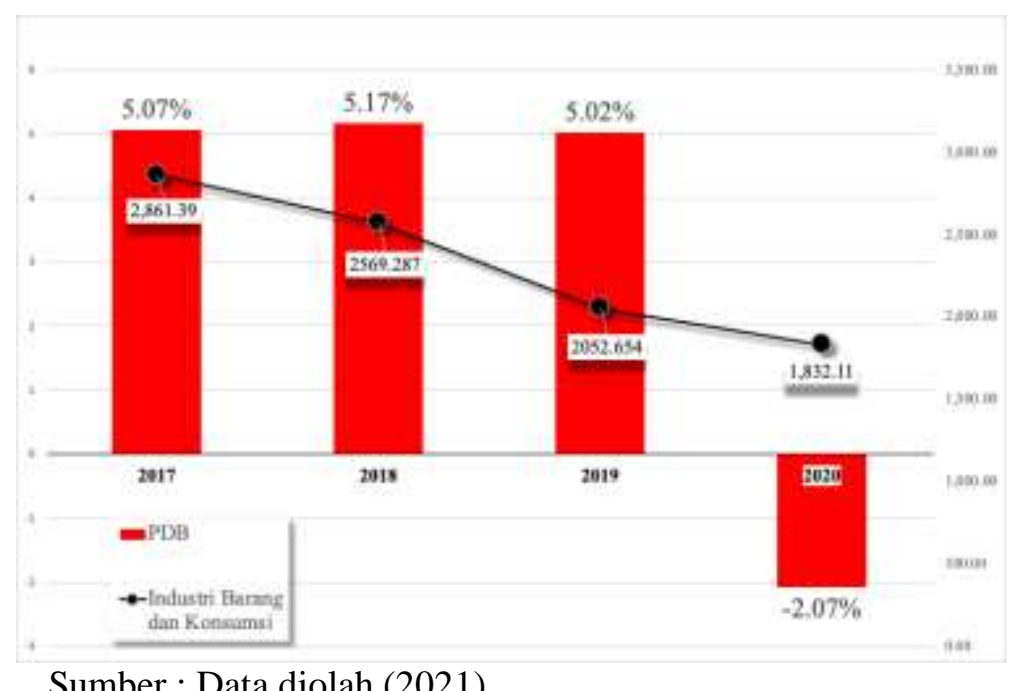

\section{Gambar 1. HARGA SAHAM INDUSTRI BARANG DAN KONSUMSI DAN PDB RI}

Harga saham yang terus mengalami penurunan akan mengakibatkan Investor mengalami krisis kepercayaan untuk melakukan investasi pada perusahaan tersebut. Penurunan rerata harga saham selama tiga tahun beruntun sejak 2018, 2019, dan 2020 yaitu $-10,21 \%,-20,11 \%$, dan 10,74\% pada gambar 1, dimaknai penurunan kekayaan investor sebagai pemegang saham (Brigham dan Ehrhardt, 2017:106). Bagi perusahaan, penurunan harga saham akan menurunkan nilai perusahaan yang akan berdampak pada penilaian buruk atas kinerjanya. Penilaian buruk atas kinerja perusahaan akan menjadi bahan pertimbangan dalam menanamkan modal pada perusahaan bagi para Investor (Rahayu dan Sari, 2018). Apabila perusahaan mengalami kesulitan dalam mendapatkan tambahan modal, aktivitas operasi perusahaan juga akan terganggu dan akibat terburuk adalah kebangkrutan (Darmadji, 2006:6).

Fluktuasi harga saham perusahaan yang terbentuk di bursa terjadi setiap waktu yang disebabkan kekuatan permintaan dan penawaran. Karena tingginya permintaan saham akan memengaruhi naiknya harga saham dan juga sebaliknya (Anoraga dan Pakarti, 2008:59). Kemudian menurut Mubaroq dan Afifudin (2020), Faktor internal dan eksternal perusahaan pun turut memengaruhi fluktuasi harga saham. Moeljadi (2006:67-75), pembelian saham oleh investor didasarkan pada informasi mengenai kinerja perusahaan dalam laporan keuangan menggunakan rasio keuangan perusahaan melalui perbandingan terhadap rasio yang dimiliki oleh perusahaan lain. Brigham dan Houston (2019:128) menyatakan bahwa penggunaan rasio keuangan sangat membantu dalam melakukan evaluasi laporan keuangan dengan membandingkan ke rata-rata perusahaan di industri. Hal ini membuktikan bahwa harga saham dipengaruhi laporan keuangan yang merupakan faktor internal perusahaan.

Menurut Brigham dan Houston (2019:107), evaluasi atas laporan keuangan dilakukan oleh investor dengan rasio keuangan. Rasio keuangan yang digunakan adalah kemampuan perseroan melakukan pembayaran atas seluruh tanggungan finansial yang dimiliki pada saat masa tenggat telah tiba (likuiditas), kemampuan yang dimiliki perseroan untuk membayar keseluruhan tanggungan finansial apabila harus mengalami likuidasi (solvabilitas), kemampuan perseroan untuk melakukan pengelolaan aktiva (aktivitas), kemampuan perseroan menciptakan keuntungan (profitabilitas), dan rasio nilai pasar yang memberikan informasi tentang bagaimana Investor memandang tentang perusahaan dan prospek masa depan (Brigham dan Houston, 2019:107).

Pendekatan rasio profitabilitas digunakan untuk memastikan dan mengetahui kondisi perseroan. Brigham dan Houston (2019:118) menyatakan profitabilitas menunjukkan hasil atau luaran (output) kebijakan pendanaan dan kebijakan operasional perusahaan. Profitabilitas menggambarkan seberapa banyak keuntungan yang dihasilkan perusahaan. Keuntungan yang diperoleh menyebabkan pertambahan nilai kas perusahaan. Weston dan Brigham (2004:26) menyatakan tingkat keuntungan yang diciptakan perusahaan termasuk satu dari sekian faktor yang memengaruhi harga saham. 
Tingginya tambahan nilai kas perusahaan akan meningkatkan nilai perusahaan kemudian meningkatkan harga saham. Angka profitabilitas perseroan dan pembentukan harga saham berbanding lurus (Brigham dan Ehrhardt, 2017:106).

Rasio keuangan yang digunakan sebagai indikator dalam menilai profitabilitas suatu perusahaan adalah ROA, ROE, dan NPM (Wiagustini, 2014:90). ROA mengukur tingkat keuntungan berdasarkan kepemilikan aset perseroan (Brigham dan Houston, 2019:119). Penelitian terdahulu yang dilakukan Arkan (2016), Sukmawati dan Garsela (2016), Watung dan Ilat (2016), Anwaar (2016), Bahri (2018) serta Cahyaningrum dan Antikasari (2017), menemukan pengaruh positif signifikan dalam ROA terhadap harga saham. Sedangkan Bashir dan Amir (2018) dan Darnita (2012), pengaruh ROA terhadap harga saham adalah negatif signifikan. Namun, hasil penelitian Vora (2018), Egam et al. (2017), dan Tamuntuan (2015) menemukan harga saham dipengaruhi ROA secara non signifikan.

ROE adalah rasio pengukur tingkat keuntungan berdasarkan total ekuitas para pemegang saham (Brigham dan Houston, 2019:119). Penelitian tentang ROE yang dilakukan Arkan (2016), Kamar (2017), Bahri (2018), Ambarwati et al. (2019), dan Cahyaningrum dan Antikasari (2017) menemukan hasil positif signifikan pada harga saham. Sedangkan, Sukmawati dan Garsela (2016) dan Bashir dan Amir (2018) menemukan pengaruh negatif signifikan pada harga saham. Kemudian hasil non signifikan harga saham oleh ROE ditemukan oleh Nino et al. (2016), Anwaar (2016), Vora (2018), Egam et al. (2017), dan Hunjra et al. (2014).

NPM adalah rasio pengukur laba bersih setelah pengenaan pajak (Brigham dan Houston, 2019:118). Penelitian Arkan (2016), Watung dan Ilat (2016), dan Anwaar (2016) menemukan bahwa ada pengaruh positif yang signifikan dalam harga saham oleh NPM. Hasil negatif yang signifikan pada NPM terhadap harga saham ditemukan Murniati (2016) dan Egam et al. (2017). Ambarwati et al. (2019) dan Hutapea et al. (2017) menemukan hasil non signifikan.

Berdasarkan fenomena gap pada penurunan harga saham sektor industri barang dan konsumsi selama tiga tahun berturut-turut sejak 2018-2020 , data tentang PDB RI sejak 2017-2020 serta research gap di atas, tujuan penelitian ini untuk mengetahui pengaruh dari ROA, ROE, dan NPM terhadap harga saham perusahaan sektor industri barang dan konsumsi di BEI tahun 2017-2020.

\section{KAJIAN PUSTAKA DAN PENGEMBANGAN HIPOTESIS}

\section{Teori Sinyal}

Asymmetric information adalah keadaan ketika pengelola perseroan mempunyai informasi yang lebih maju tentang pandangan masa depan perseroan daripada investor (Brigham dan Houston, 2019:499). Teori sinyal adalah tindakan atau kegiatan manajemen suatu perusahaan memberikan indikasi atau sinyal kepada Investor untuk menilai prospek masa depan mengenai bagaimana pengelolaan perseroan (Brigham dan Houston, 2019:500). Perseroan berprospek potensial tak mengumpulkan dana melalui peluncuran saham baru, sedangkan perseroan berprospek kurang potensial akan mengumpulkan pendanaan dengan penawaran saham baru (Brigham dan Houston, 2011:186). Sinyal merupakan sarana pemberian penjelasan positif atau negatif pada para stakeholders melalui laporan keuangan (Brigham dan Houston, 2019:500). Laporan keuangan menjadi instrumen atau sinyal yang dikeluarkan oleh perusahaan untuk menginformasikan prospek masa depan (Godfrey et al., 2010:375).

\section{Harga Saham}

Harga saham adalah valuasi pada jangka waktu tertentu yang terbentuk oleh kekuatan permintaan dan penawaran serta investor di pasar bursa (Anoraga dan Pakarti, 2008:59). Bagi Investor, harga saham merupakan tolok ukur atas kesejahteraan pemegang sahamnya. Harga saham adalah hal penting yang harus diperhatikan bagi perusahaan karena merupakan refleksi dari nilai perusahaan di mata Investor (Rahayu dan Sari, 2018). Volatilitas valuasi di pasar berbanding lurus dengan nilai perusahaan tersebut. Menurut Brigham dan Ehrhardt (2017:106) maksimalisasi harga saham berbanding lurus 
Mohammad Rizqi Hisbullah. Pengaruh Profitabilitas terhadap Harga Saham Perusahaan Sektor Industri Barang dan Konsumsi di BEI Tahun 2017-2020

dengan maksimalisasi harta milik pemegang saham. Harga saham dipengaruhi jumlah lalu lintas aliran kas yang dikehendaki oleh perusahaan di masa mendatang (Brigham dan Ehrhardt, 2017:106). Harga saham yang difungsikan sebagai acuan penelitian adalah harga saham penutupan (closing price) (Wulandari dan Badjra, 2019).

\section{Net Profit Margin}

NPM adalah pengukur keuntungan bersih pasca pengenaan pajak. NPM dihitung melalui pembagian atas untung bersih pada total penjualan (Brigham dan Houston, 2019:118). Semakin tinggi nilai NPM, semakin produktif perusahaan dalam menjalankan aktivitas bisnisnya yang akan memengaruhi kepercayaan Investor kemudian memengaruhi permintaan saham berujung akan meningkatkan harga saham (Kasmir, 2012:77).

\section{Return On Assets}

ROA adalah pengukur tingkat keuntungan berdasarkan kepemilikan aset perseroan (Brigham dan Houston, 2019:119). Nilai ROA, kinerja, keuntungan, permintaan saham, dan harga saham memiliki hubungan yang linier. Keuntungan tinggi menarik permintaan saham dan diikuti peningkatan harga saham. Harga saham berjalan secara positif seiring dengan ROA (Darmadji, 2006:6).

\section{Return On Equity}

ROE adalah pengukur tingkat keuntungan berdasarkan total ekuitas pemegang saham (Brigham dan Houston, 2019:119). ROE berbanding lurus dengan harga saham. Saat terjadi peningkatan pada ROE, kenaikan harga saham akan mengikuti yang didahului permintaan saham. Alokasi modal dalam memeroleh keuntungan adalah hal yang dilihat investor (Kasmir, 2012:77).

\section{Hubungan antar Variabel}

Nilai NPM berbanding lurus dengan permintaan saham dan harga saham (Kasmir, 2012:77). Nilai NPM juga menunjukkan efisiensi perusahaan dalam mendapatkan keuntungan dari penjualan yang dilakukan (Brigham dan Houston, 2019:118). Penelitian Arkan (2016), Watung dan Ilat (2016), dan Anwaar (2016) menghasilkan temuan pengaruh positif signifikan dalam NPM terhadap harga saham. Maka, hipotesis riset ini yang pertama adalah:

H1: Harga saham dipengaruhi net profit margin.

Nilai ROA yang positif mencerminkan efisiensi perusahaan dalam menciptakan profit yang menarik minat Investor dalam menanamkan dana pada saham perusahaan yang menyebabkan kenaikan harga saham (Darmadji, 2006:6). Riset milik Arkan (2016), Sukmawati dan Garsela (2016), Watung dan Ilat (2016), Anwaar (2016), Bahri (2018), dan Cahyaningrum dan Antikasari (2017) berhasil menemukan pengaruh positif dan signifikan dalam ROA terhadap harga saham. Maka, hipotesis riset ini yang kedua adalah:

\section{H2: Harga saham dipengaruhi return on assets}

Nilai ROE positif merefleksikan kemampuan perseroan menciptakan laba dari alokasi investasi pemegang saham yang positif. Hal itu membuat ROE memengaruhi pemegang saham untuk melakukan permintaan saham yang kemudian memengaruhi kenaikan harga saham (Kasmir, 2012:77). Penelitian yang dilakukan oleh Arkan (2016), Kamar (2017), Bahri (2018), Ambarwati et al. (2019), dan Cahyaningrum dan Antikasari (2017) mendapati pengaruh positif dan signifikan terhadap harga saham pada ROE. Maka, hipotesis riset ini yang ketiga adalah:

H3: Harga saham dipengaruhi return on equity

Model penelitian ditunjukkan pada Gambar 2 


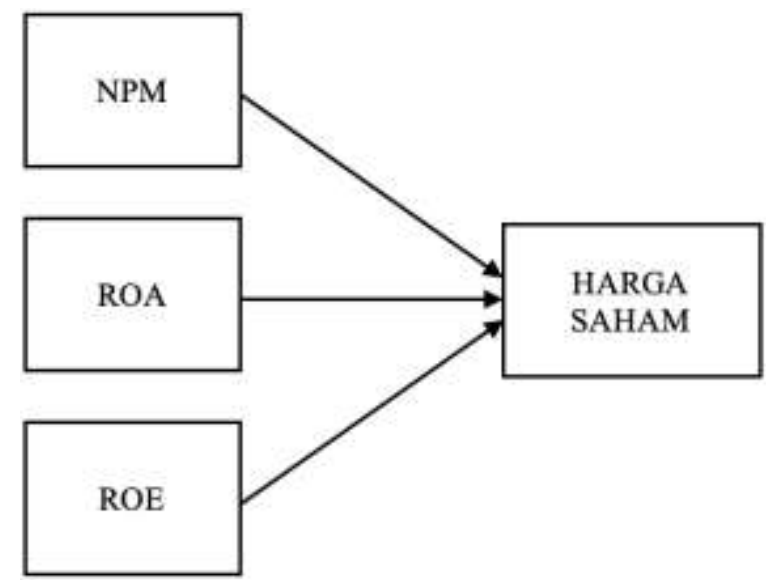

Sumber : Data diolah (2021)

\section{Gambar 2. MODEL PENELITIAN}

\section{METODE PENELITIAN}

Penelitian kausal kuantitatif digunakan mencari pengaruh variabel independen terhadap variabel dependen. Riset ini dilakukan pada perusahaan yang terdaftar di BEI sektor industri barang dan konsumsi periode 2017-2020. NPM (X1), ROA (X2), dan ROE (X3) adalah variabel independen dan harga saham adalah variabel dependen (Y). Objek penelitian adalah perusahaan di sektor industri barang dan konsumsi periode 2017-2020.

Metode penentuan sampel adalah purposive sampling. Kriteria pengambilan sampel pada perusahaan yang terdaftar di BEI sektor industri barang dan konsumsi yang tak mengalami delisting dan menyediakan informasi yang dibutuhkan selama 2017 hingga 2020 secara berturut-turut. Jumlah sampel yang diperoleh adalah 120 sampel. Teknik analisis data menggunakan regresi linear berganda dengan SPSS Statistics 26.0 for Mac.

\section{HASIL DAN PEMBAHASAN}

\section{Hasil Uji Statistik}

Sebelum melakukan uji regresi linier berganda, uji asumsi klasik yang meliputi normalitas; linieritas; multikolinieritas; heteroskedasitas; dan autokorelasi terlebih dahulu dilakukan. 120 sampel yang telah ditetapkan harus dilakukan eliminasi menjadi 90 sampel karena data tidak normal.

\section{Uji Normalitas}

Hasil pada Tabel 1 dengan uji Kolmogorov-Smirnov, menunjukkan angka sig. sebesar 0,06 di atas $0,05(0,06>0,05)$ (Ghozali, 2018:111). Hasil uji normalitas menunjukkan penggunaan sampel berdistribusi normal.

Tabel 1.

HASIL UJI NORMALITAS

\begin{tabular}{lr}
\hline & Unstandardized Residual \\
\hline Jumlah data & 90 \\
Sig. & $\mathbf{0 , 0 6}$ \\
\hline Sumber : Data diolah (2021) &
\end{tabular}


Mohammad Rizqi Hisbullah. Pengaruh Profitabilitas terhadap Harga Saham Perusahaan Sektor Industri Barang dan Konsumsi di BEI Tahun 2017-2020

\section{Uji Multikolinieritas}

Dari nilai tolerance dan VIF hasil uji multikolinieritas, hasil uji variabel ROA adalah 0,121 dan 8,263. Kemudian variabel ROE adalah 0,138 dan 7,259 serta hasil uji variabel NPM adalah 0,387 dan 2,586. Dari hasil uji statistik tersebut, didapati hasil bahwa tak terdapat multikolinieritas di antara variabel penelitian karena memiliki angka tolerance > 0,1 dan angka Variance Inflation Factor (VIF) < 10 (Ghozali, 2018:105).

\section{Uji Heteroskedasitas}

Hasil uji heteroskedasitas menggunakan nilai koefisien korelasi Rank Spearman dari variabel ROA, ROE, dan NPM adalah 0,153, 0,425, dan 0,144. Menurut Ghozali (2018:139) hasil pengujian statistik nilai koefisien korelasi antar variabel bebas dengan variabel pengganggu pada model regresi memiliki nilai probabilitas $(\mathrm{sig})>0,05$. Sehingga tak ditemui gejala heteroskedasitas.

\section{Uji Autokorelasi}

Hasil uji autokorelasi Durbin-Watson mendapatkan angka 1,833 pada model regresi. Nilai dU dan 4dU untuk 90 sampel dan 3 variabel adalah 1,7264 dan 2,2736. Nilai uji Durbin-Watson model regresi adalah dU < 1,833 < 4-dU. Tak terdapat autokorelasi dengan nilai uji yang berada di antara 4-dU dan dU (Ghozali, 2018:112)

\section{Regresi Linier Berganda}

Tabel 2 menunjukkan nilai uji regresi linier berganda dengan persamaan regresi (1). Didapati nilai konstanta 473,997 satuan dengan arti harga saham perusahaan sebesar 473,997 satuan apabila seluruh variabel bernilai konstan. Koefisien regresi ROE sebesar 73,802 dengan arti setiap peningkatan ROE, maka harga saham akan meningkat 73,802 satuan.

$Y=473,997+73,802 R O E$

\section{HASIL UJI REGRESI LINIER BERGANDA}

\begin{tabular}{lrrl}
\hline Model & Koefisien Regresi & \multicolumn{1}{c}{ T } & Sig. \\
\hline (Constant) & 473,997 & 3,233 & 0,002 \\
NPM & $-10,854$ & $-0,525$ & 0,601 \\
ROA & $-13,901$ & $-0,278$ & 0,782 \\
ROE & 73,802 & 2,173 & 0,033 \\
\hline
\end{tabular}

Sumber : Data diolah (2021)

\section{Uji Statistik F}

Hasil tabel 3 menunjukkan angka $F$ hitung adalah 6,875 dengan nilai probabilitas 0,000. Jadi, keseluruhan variabel yang memengaruhi harga saham secara simultan terbukti berpengaruh.

\section{Tabel 3. \\ REKAP UJI F DAN UJI R}

\begin{tabular}{lrr}
\hline Variabel & Value & \multicolumn{2}{c}{ Sig. } \\
\hline F Test & 6,875 & 0,000 \\
Adj. R Square & 0,165 & 0,165 \\
\hline
\end{tabular}

Sumber : Data diolah (2021)

\section{Uji Statistik t}

Tabel 2 menyajikan angka t hitung variabel ROE sebesar 2,173 dan angka (sig) 0,033 < 0,05. Jadi, dapat diartikan terima $\mathrm{H} 1$ dan tolak H0. Harga saham tak terbukti signifikan dengan pengaruh ROA dan NPM karena nilai (sig) > 0,05 sehingga terima H0 dan tolak H1. 


\section{Uji Determinasi}

Tabel 3 menunjukkan nilai Adj. R Square sebesar 0,165 atau 16,5\%. Variabel independent pada penelitian ini menjelaskan sebanyak $16,5 \%$ terhadap variabel dependen, sedangkan $83,5 \%$ dijelaskan oleh variabel independen lain diluar model regresi.

\section{Pengaruh NPM terhadap Harga Saham}

NPM tidak berpengaruh terhadap harga saham. Nilai NPM yang non signifikan terhadap harga saham tidak menunjukkan efisiensi perusahaan dalam mendapatkan keuntungan dari penjualan yang dilakukan (Brigham dan Houston, 2019:118). Hasil ini tidak berbanding lurus dengan teori sinyal bahwa indikator dalam laporan keuangan (NPM) akan memberikan prospek masa depan perusahaan (Godfrey et al., 2010:375). Temuan ini tidak sesuai Kasmir (2012:77), bahwa NPM berbanding lurus dengan harga saham. Hal ini sejalan dengan penelitian Ambarwati et al. (2019) dan Hutapea et al. (2017) yang menyatakan harga saham tidak dipengaruhi NPM secara signifikan.

Hal ini dikarenakan harga saham dapat dipengaruhi faktor lain di luar variabel riset. Hasil uji juga menunjukkan nilai rata-rata NPM sebesar 7,97\%. Efisiensi biaya oleh perusahaan dalam menghasilkan laba bersih masih rendah, sehingga menghasilkan nilai NPM yang rendah dan tidak berdampak terhadap harga saham. Dari hasil tabulasi NPM dengan harga saham, nilai NPM tidak berkaitan dengan harga saham. Artinya tidak ada sinkronisasi antara NPM dengan harga saham. Bagi investor sektor industri barang dan konsumsi, valuasi NPM tidak direkomendasikan untuk dipertimbangkan secara dalam karena nilai yang non signifikan sehingga tidak membawa dampak bagi harga saham.

\section{Pengaruh ROA terhadap Harga Saham}

Harga saham tidak terbukti dipengaruhi ROA. Nilai ROA yang non signifikan tidak mencerminkan efisiensi perusahaan dalam menciptakan profit yang menarik minat Investor dalam menanamkan dana pada saham perusahaan yang menyebabkan kenaikan harga saham (Darmadji, 2006:6). Hasil ini tidak sejalan dengan teori sinyal bahwa indikator dalam laporan keuangan (ROA) akan memberikan prospek masa depan perusahaan (Godfrey et al., 2010:375). Kemudian, temuan penelitian ini juga bertentangan dengan konsep harga saham yang dipengaruhi (Darmadji, 2006:6). Hal ini sejalan dengan Vora (2018), Egam et al. (2017), dan Tamuntuan (2015) yang menemukan bahwa ROA tidak berdampak signifikan pada harga saham.

Hal ini dikarenakan ada faktor lain yang dapat memengaruhi harga saham perseroan. Dari hasil tabulasi ROA dengan harga saham, nilai ROA tidak sejalan baik positif maupun negatif terhadap harga saham. Hasil uji juga menunjukkan nilai rata-rata ROA adalah 6,26\%. Pengelolaan aset oleh perusahaan dalam menghasilkan laba masih rendah, sehingga ROA memiliki nilai yang rendah dan tidak berdampak pada harga saham. Tidak terjadi sinkronisasi antara ROA dengan harga saham. Bagi investor sektor industri barang dan konsumsi, valuasi ROA tidak direkomendasikan untuk dipertimbangkan secara dalam karena nilai yang non signifikan sehingga tidak membawa dampak bagi harga saham.

\section{Pengaruh ROE terhadap Harga Saham}

ROE terbukti berdampak secara signifikan pada harga saham. Nilai ROE positif merefleksikan kemampuan perseroan menciptakan laba dari alokasi investasi pemegang saham yang positif. Hal itu membuat ROE memengaruhi pemegang saham untuk melakukan permintaan saham yang kemudian memengaruhi kenaikan harga saham (Kasmir, 2012:77). Output penelitian ini sejalan dengan teori sinyal bahwa indikator dalam laporan keuangan (ROE) akan memberikan prospek masa depan perusahaan (Godfrey et al., 2010:375). Temuan ini juga sejalan dengan konsep Kasmir (2012:77), bahwa ROE mencerminkan kemampuan perseroan menciptakan keuntungan dari alokasi investasi pemegang saham yang memengaruhi Investor melakukan permintaan saham yang kemudian memengaruhi kenaikan harga saham. Penemuan serupa dalam riset Arkan (2016), Kamar (2017), Bahri (2018), Ambarwati et al. (2019), dan Cahyaningrum dan Antikasari (2017) berbuah pengaruh positif dan signifikan pada harga saham oleh ROE. 
Hasil uji menunjukkan angka rata-rata ROE adalah 9,67\%. Pengelolaan ekuitas perusahaan dalam menghasilkan laba yang ditunjukkan dengan nilai ROE sebagai sinyal untuk menginformasikan prospek masa depan perusahaan, berbanding lurus dengan teori sinyal (Godfrey et al., 2010:375). Nilai ROE yang positif pada perusahaan sektor industri barang dan konsumsi diharapkan untuk terus dijaga dan dimanfaatkan untuk optimalisasi aliran modal yang masuk melalui pembelian saham. Karena, nilai ROE memengaruhi harga saham perusahaan yang juga merepresentasikan kekayaan pemegang saham. Bagi investor sektor industri barang dan konsumsi, valuasi ROE direkomendasikan untuk dipertimbangkan secara dalam karena nilai yang signifikan sehingga membawa dampak bagi harga saham.

\section{KESIMPULAN}

Penelitian ini membuktikan bahwa ROA dan NPM tidak memengaruhi harga saham. ROE merupakan faktor yang memberi pengaruh harga saham perusahaan sektor industri barang dan konsumsi pada tahun 2017-2020 secara positif signifikan. ROE merefleksikan kemampuan perseroan menciptakan laba dari alokasi investasi pemegang saham yang positif. Hal itu membuat ROE memengaruhi pemegang saham untuk melakukan permintaan saham yang kemudian memengaruhi kenaikan harga saham. Dapat disimpulkan penurunan harga saham selama 2018 hingga 2020 disebabkan oleh pengaruh ROE yang dianggap negatif oleh para pemegang saham sehingga menurunkan permintaan saham perusahaan. Perusahaan hendaknya memerhatikan ROE untuk menarik investor. Peningkatan ROE akan memengaruhi kenaikan harga saham.

Keterbatasan dari penelitian ini adalah variabel independen yang kurang bervariasi, sehingga kurang bisa memberikan gambaran secara jelas mengenai faktor apa saja yang memengaruhi harga saham. Hasil penelitian diharapkan dapat berguna oleh perusahaan sektor industri barang dan konsumsi memertimbangkan ROE dalam meningkatkan harga sahamnya. Untuk penelitian selanjutnya, penggunaan variabel seperti rasio aktivitas, likuiditas, dan solvabilitas perlu dipertimbangkan.

\section{DAFTAR PUSTAKA}

Ambarwati, P., Enas, E., dan Lestari, M. N. (2019). Pengaruh Net Profit Margin (NPM) dan Return On Equity (ROE) terhadap Harga Saham (Studi Kasus Pada PT. Bank Central Asia Tbk, yang Terdaftar di Bursa Efek Indonesia Periode 2007-2017). Business Management and Extrepreneurship Journal, 1(2), 100-119.

Anoraga, P., dan Pakarti, P. (2008). Pengantar Pasar Modal. Jakarta: PT. Rineka Cipta.

Anwaar, M. (2016). Impact of Firms' Performance on Stock Returns (Evidence from Listed Companies of FTSE-100 Index London, UK). Global Journal of Management and Business Research, 16(1), 31-39.

Arkan, T. (2016). The Importance of Financial Ratios in Predicting Stock Price Trends: A Case Study in Emerging Markets. Zeszyty Naukowe Uniwersytetu Szczecińskiego Finanse Rynki Finansowe Ubezpieczenia, 79(1), 13-26. (https://doi.org/10.18276/frfu.2016.79-01, diakses pada 24 Oktober 2020).

Bahri, S. (2018). Pengaruh Kinerja Keuangan terhadap Harga Saham. JRAK: Jurnal Riset Akuntansi dan Komputerisasi Akuntansi, 9(1), 1-21. (https://doi.org/10.33558/jrak.v9i1.1358, diakses pada 24 Oktober 2020).

Bashir, A., dan Amir, A. (2018). Profitability and Share Price: a Comparative Study Among the Textile and Cement Sector of Pakistan. Sci-Int.(Lahore), 30(2), 197-201.

BPS. 2021. Produk Domestik Bruto (PDB). (https://www.bps.go.id/subject/169/produk-domestikbruto--pengeluaran-.html, diakses pada tanggal 5 April 2021). 
Brigham, E. F., dan Ehrhardt, M. C. (2017). Financial Management Theory dan Practice (kelima belas). Boston: Cengage Learning.

Brigham, E. F., dan Houston, J. F. (2011). Dasar-Dasar Manajemen Keuangan (kedua). Jakarta: Salemba Empat.

Brigham, E. F., dan Houston, J. F. (2019). Fundamentals Of Financial Management (kelima belas). Boston: Cengage Learning.

Bursa Efek Indonesia. 2018. Indeks. (https://www.idx.co.id/produk/indeks/, diakses pada 25 Maret 2021).

Cahyaningrum, Y. W., dan Antikasari, T. W. (2017). Pengaruh Earning Per Share, Price To Book Value, Return on Asset, dan Return on Equity terhadap Harga Saham Sektor Keuangan. Jurnal Economia, 13(2), 191. (https://doi.org/10.21831/economia.v13i2.13961, diakses pada 24 Oktober 2020).

Darmadji, T. (2006). Pasar Modal Indonesia. Jakarta: Salemba Empat.

Darnita, E. (2012). Analisis Pengaruh Return on Assets (ROA), Return on Equity (ROE), Net Profit Margin (NPM) dan Earning Per Share (EPS) Terhadap Harga Saham (Studi Pada Perusahaan Food Dan Beverages Yang Terdaftar Di Bursa Efek Indonesia (BEI) Pada Tahun 2008-2012). Jurnal Ekonomi dan Bisnis, 1(2), 81-87.

DetikFinance. (2017). Ditopang Sektor Makanan, Industri Makanan Tumbuh 5,51\%. (https://finance.detik.com/berita-ekonomi-bisnis/d-3709189/ditopang-sektor-makanan-industrimanufaktur-tumbuh-551, diakses pada 22 April 2021)

Egam, G. E. Y., Ilat, V., dan Pengerapan, S. (2017). Pengaruh Return On Asset (Roa), Return On Equity (Roe), Net Profit Margin (NPM), dan Earning Per Share (EPS) terhadap Harga Saham Perusahaan yang Tergabung dalam Indeks Lq45 Di Bursa Efek Indonesia Periode Tahun 20132015. Problems of a Mature Economy, 5(1), 45-61. (https://doi.org/10.1007/978-1-349-154005_6, diakses pada 24 Oktober 2020).

Ghozali, I. (2018). Aplikasi Analisis Multivariete SPSS 25 (kesembilan). Semarang: Universitas Diponegoro.

Godfrey, J., Hodgson, A., Tarca, A., Hamilton, J., dan Holmes, S. (2010). Accounting Theory (ketujuh). Sydney: WileydanSons.

Hunjra, I. H., Shehzhad, M., Chani, M. I., Hassan, S., dan Mustafa, U. (2014). Impact of Dividend Policy, Earning per Share, Return on Equity, Profit after Tax on Stock Prices. International Journal of Economics and Empirical Research, 2(3), 109-115.

Hutapea, A. W., Saerang, I. S., dan E., T. J. (2017). Pengaruh Return on Assets, Net Profit Margin, Debt To Equity Ratio, dan Total Assets Turnover terhadap Harga Saham Industri Otomotif dan Komponen yang Terdaftar di Bursa Efek Indonesia. Jurnal EMBA, 5(2), 541-551.

Kamar, K. (2017). Analysis of the Effect of Return on Equity (ROE) and Debt to Equity Ratio (DER) on Stock Price on Cement Industry Listed In Indonesia Stock Exchange (Idx) In the Year of 2011-2015. IOSR Journal of Business and Management, 19(05), 66-76. (https://doi.org/10.9790/487X-1905036676, diakses pada 24 Oktober 2020).

Karya, D., dan Syamsuddin, S. (2016). Makroekonomi Pengantar Untuk Manajemen. Jakarta: Rajawali Press. 
Mohammad Rizqi Hisbullah. Pengaruh Profitabilitas terhadap Harga Saham Perusahaan Sektor Industri Barang dan Konsumsi di BEI Tahun 2017-2020

Kasmir. (2012). Analisis Laporan Keuangan. Jakarta: PT Raja Grafindo Persada.

Mankiw, N. G. (2010). Macroeconomics (ketujuh). New York: Worth Publishers.

Moeljadi. (2006). Manajemen Keuangan Pendekatan Kuantitatif dan Kualitatif. Yogyakarta: BPFE.

Mubaroq, A., dan Afifudin, H. (2020). Faktor Internal dan Eksternal Yang Memengaruhi Pergerakan Harga Saham Perusahaan Manufaktur di Bursa Efek Indonesia Tahun 2016-2019. Jurnal Ilmiah Riset Akuntansi, 9(1), 100-116.

Murniati, S. (2016). Effect Of Capital Structure, Company Size And Profitability on the Stock Price of Food And Beverage Companies Listed on the Indonesia Stock Exchange. Information Management And Business Review, 8(1), 23-29.

Nino, Y., Murni, S., dan R. Tumiwa, J. (2016). Analisis Ukuran Perusahaan, Struktur Modal, Non Perfo Rming Loan (NPL), Capital Adequacy Ratio (CAR), dan Return On Equity (ROE) terhadap Harga Saham Perusahaan Perbankan Pada Indeks Lq45. Jurnal EMBA, 4(3), 717-728.

Rahayu, M., dan Sari, B. (2018). Faktor-faktor yang memengaruhi nilai perusahaan. Jurnal Sosial dan Humaniora, 2(1), 69-76.

Sukmawati, F., dan Garsela, I. (2016). The Effect of Return on Assets and Return on Equity to the Stock Price. Proceedings of the 2016 Global Conference on Business, Management and Entrepreneurship, 15, 53-57. (https://doi.org/10.2991/gcbme-16.2016.8, diakses pada 24 Oktober 2020).

Tamuntuan, U. (2015). Analysing The Effect of Return on Equity, Return on Assets and Earnings Per Share Toward Share Prices: An Empirical Study of Food and Beverage Companies Listed On Indonesia Stock Exchange. Jurnal Berkala Ilmiah Efisiensi, 15(05), 446-574. (https://media.neliti.com/media/publications/2662-EN-the-effect-of-earnings- per-share-epsreturn-on-equity-roe-on-stock-price-of-bank.pdf, diakses pada 28 Maret 2021).

Vora, K. (2018). Influence of Financial Performance Indicators on Market Price of Shares of Nifty 50 Companies. International Journal of Advance Research in Computer Science and Management Studies, 6(2), 67-75.

Watung, R., dan Ilat, V. (2016). Pengaruh Return on Asset (ROA), Net Profit Margin (NPM), dan Earning Per Share (EPS) terhadap Harga Saham pada Perusahaan Perbankan di Bursa Efek Indonesia Periode 2011-2015. Jurnal Riset Ekonomi, Manajemen, Bisnis dan Akuntansi, 4(2), 518-529. (https://doi.org/10.35794/emba.v4i2.13108, diakses pada 24 Oktober 2020).

Wiagustini, N. (2014). Manajemen Keuangan. Denpasar: Udayana University Press.

Weston, F. J., dan Brigham, E. F. (2004). Basics of Financial Management (kelima). Jakarta: Penerbit Erlangga.

Wulandari, A. I., dan Badjra, I. B. (2019). Pengaruh Profitabilitas Terhadap Harga Saham Pada Perusahaan LQ-45 di Bursa Efek Indonesia (BEI). E-Jurnal Manajemen Universitas Udayana, 8(9), 5722-5740. (https://doi.org/https://doi.org/10.24843/EJMUNUD.2019.v08.i09.p18, diakses pada 27 Maret 2021). 